\title{
Artificial Intelligence-enabled English Translation System Using Unsupervised Learning for Wireless Network
}

\section{Research Article}

Keywords:

Posted Date: February 3rd, 2022

DOI: https://doi.org/10.21203/rs.3.rs-1249163/v2

License: (9) This work is licensed under a Creative Commons Attribution 4.0 International License.

Read Full License 


\section{Abstract}

Research Square has withdrawn this preprint due to extensive overlap with another article.

\section{Full Text}

The authors have withdrawn this preprint from Research Square. 